\title{
Historical Perspective on Weed Control and Pest Management in Horticultural Crops
}

\author{
Mathieu Ngouajio ${ }^{1}$
}

AdDitionAl INDEX WORDs. inducer, disease resistance, allelopathy, climate change, soil quality

Summary. Over the last century, climate change, adoption of new regulations, and changes in cropping systems have significantly impacted weed and pest management in horticultural crops. The objective of this workshop was to provide a critical review of major changes and discuss current and future trends for weed and pest management. Speakers touched on a broad range of topics including climate change and disease dynamics, the use of disease resistance inducers, soil management for pest management, and the role of allelopathy in weed management. Major recommendations included 1) increased grower education related to the impact of climate change on plant diseases; 2) more research directed towards a better understanding of the interaction of plant-pathogen-inducer; 3) use of organic soil amendments, cover crops, crop rotations, and resistant cultivars to enhance the weed and disease suppressive effect of soils; and 4) enhancement of allelochemical production and subsequent weed suppression through conventional breeding and molecular techniques.

The central role that agriculture plays in human life dates back thousands of years (Janick and Goldman, 2003; Read, 2003). Ancient civilizations initiated agricultural production and thereby changed forever our destiny from hunters and collectors of natural products to the modern agricultural society of today (Janick and Goldman, 2003). However, our route has been and will continue to be filled with challenges, with weed control and pest management prime examples of the challenges that agriculture has faced since its inception. It is, therefore, not surprising to realize that the search for chemicals and development of crop management practices to control weeds and pests dates back to the beginning of agriculture (Janick and Goldman, 2003). Records of pest management in agriculture can be traced to $2500 \mathrm{BC}$, when Sumerians used sulfur compounds to control mites and other insects, and $950 \mathrm{BC}$, when burning was used as a cultural practice for weed, pest, and disease control (Dent, 2004). Today, horticultural production is facing new challenges, including pest and weed management in organic production systems, resistance to pesticides, the Food Quality Protection Act (FQPA), methyl bromide phaseout, and the impact of global warming on weed, pest, and disease dynamics. In view of these emerging challenges and the centennial celebration of ASHS in 2003, the Weed Control and Pest Management Working Group (WCPM) decided to organize a workshop to address some of these issues. After a follow-up discussion on the ASHS listserve, WCPM organized the workshop "Historical perspective on weed control and pest management in horticultural crops" at the centennial meeting in Providence, R.I., in 2003. Workshop speakers touched on a broad range of topics pertaining to weed control and pest management, including 1) climate change and disease risk, 2) current status on the use of disease resistance inducers, 3) soil management for pest management, and 4) use of allelopathy for weed management.

\footnotetext{
${ }^{1}$ Assistant Professor, Department of Horticulture, Michigan State University, East Lansing, MI 48824-1325; e-mail: ngouajio@msu.edu

On behalf of the Weed Control and Pest Management Working Group (WCPM) of ASHS, I would like to thank Drs. William W. Kirk (Michigan State University), Andrea B. da Rocha (Santa Catarina State University, Brazil), Milton McGiffen, Jr. (University of California, Riverside), and Leslie A. Weston (Cornell University) for their excellent presentations at the workshop. I also thank Dr. Robert Richardson and Ms. Erin Hill for their comments on the early version of this paper.
} 


\section{Climate change and disease dynamics}

The geographical distribution of plant diseases and the relative incidence of individual pathogens within a geographic area are highly affected by the climate (Chakraborty et al., 2000). Climate change can therefore have positive, negative, or neutral impacts on individual diseases (Chakraborty et al., 2000; Coakley et al., 1999; Manning and Tiedemann, 1995). Elevated carbon dioxide $\left(\mathrm{CO}_{2}\right)$ levels and global warming are some of the indices of climate change. Atmospheric $\mathrm{CO}_{2}$ has increased by about $30 \%$ since preindustrial times, which may promote foliar diseases by increasing plant canopy and relative humidity (Coakley et al., 1999; Manning and Tiedemann, 1995). Likewise, temperature also has increased between 0.3 to $0.6^{\circ} \mathrm{C}(0.54$ to $1.08^{\circ} \mathrm{F}$ ), and global temperature is predicted to rise 0.9 to $3.5^{\circ} \mathrm{C}$ ( 1.62 to $6.30^{\circ} \mathrm{F}$ ) by the year 2100 (Chakraborty et al., 2000). For example, 1998 was one of the hottest years on record with ocean and land temperatures $0.25^{\circ} \mathrm{C}$ $\left(0.450{ }^{\circ} \mathrm{F}\right)$ warmer from January to May than in previous records (Vogel and Lawler, 1998). In the U.S., Sept. 1998 had a mean temperature of 20.6 ${ }^{\circ} \mathrm{C}\left(69.08^{\circ} \mathrm{F}\right)$, the hottest month over 104 years of records, with the previous record being $20.2^{\circ} \mathrm{C}\left(68.36^{\circ} \mathrm{F}\right)$ (Coakley et al., 1999).

Baker et al. (2005) presented a case study on the effect of climate changes on potato late blight (Phytophthora infestans) risk in the upper Great Lakes region. Over the years, the historical potato (Solanum tuberosum) growing season in the region has become warmer, wetter, and more humid, resulting in increased risk of potato late blight (Baker et al., 2005). This has significant implications for disease management. Some of the recommendations proposed included 1) reevaluation of the threshold values for humidity and temperature values for models using disease severity values, 2 ) increased and improved education of growers, and 3) use of an integrated disease management approach.

\section{Use of disease resistance inducers}

The use of disease resistance inducers is becoming a key component of integrated pest management in horticultural crops. With the loss of key pesticides due to health and environmental concerns coupled with the growth of organic production, the enhancement of natural plant defense mechanisms is needed more than ever before in our pest management toolbox. Da Rocha and Hammerschmidt (2005) presented an overview on the use of disease inducers in horticulture. In the last few years significant progress has been achieved in this area, with some products currently available commercially (Da Rocha and Hammerschmidt, 2005). Future research recommendations included a better understanding of the tridimensional interaction between the plant, the pathogen, and the inducer.

\section{Soil management for pest management}

The relationship between soil quality or soil health and crop productivity has been recognized since the beginning of agriculture (Carter et al., 1997). McGiffen et al. (2003) reiterated the significant impact of loss of most pesticides on cost-effective crop production, and the need to develop alternative management strategies. Since the soil is the reservoir for most weed seeds, insects, nematodes, and diseases, soil management should therefore be an integral component of pest management (Ahonsi et al., 2002; Kremer and Jianmei, 2003; Magdoff, 2001; McGiffen et al. 2003; Quimby et al., 2002). Proposed management strategies that enhance weed and disease suppressive soils included organic soil amendments, use of cover crops, crop rotations, and use of insect and disease resistant cultivars.

\section{Use of allelopathy for weed management}

Weston (2005) provided an overview of the major developments in the area of allelopathy and its potential for weed management in agricultural systems. Nonchemical weed suppression through production and release of allelochemicals is well documented in plant species in general, and cover crops in particular (Einhellig and Ramussen, 1989; Herrero et al., 2001; Liebl et al., 1992; Liebman and Davis, 2000; Ohno and Doolan, 2001; Ohno et al., 2000; Putnam 1983, 1988; Rice, 1995; Shilling et al., 1985; Teasdale, 1998; Weston; 1996). The study of allelopathy has been hampered due to the difficulty in separating allelopathic effects from competition for resources, especially under field conditions. In recent years, however, development of advanced chemical separation and structure elucidation technologies have marked a milestone in this field (Kato-Noguchia et al., 2002; Weston, 2005; Weston and Duke, 2003). These technologies include high performance liquid chromatography, high-resolution mass spectrometry, ${ }^{1} \mathrm{H}$ and ${ }^{13} \mathrm{C}$ nuclear magnetic resonance spectroscopy, electron impact mass spectrometry, and ultraviolet-visible light absorption. Significant progress has been made to elucidate the mode of action of many allelochemicals (Weston and Duke, 2003). As we continue to reduce our dependence on synthetic herbicides, use of allelopathy, or "nature's own herbicides," will play a central role in cropping systems (Putnam 1983, 1988; Singh et al., 2003). Future research focus should include enhancement of allelochemical production by crops and cover crops through conventional breeding and molecular techniques (Singh et al., 2003; Weston, 2005).

\section{Literature cited}

Ahonsi, M.O., D.K Berner, A.M Emechebe, and S.T. Lagoke. 2002. Selection of rhizobacterial strains for suppression of germination of Striga hermonthica (Del.) Benth. seeds. Biol. Control 24:143-152.

Baker, K.M., W.W. Kirk, J.M.Stein, and J.A. Andresen. 2005. Climatic trends and potato late blight risk in the upper Great Lakes region. HortTechnology 15:510-518.

Carter, M.R., E.G. Gregorich, D.W. Anderson, J.W. Doran, H.H. Janzen, and F.J. Pierce. 1997. Concepts of soil quality and their significance, p. 1-19. In: E.G. Gregorich and M.R. Carter (eds.). Soil quality for crop production and ecosystem health. Developments in soil science 25. Elsevier, Amsterdam, The Netherlands.

Chakraborty, S., A.V. Tiedemann, and P.S Teng. 2000. Climate change: Potential impact on plant diseases. Environ. Pollution 108:317-326.

Coakley, S.M., H. Scherm, S. Chakraborty. 1999. Climate change and plant disease management. Annu. Rev. Phytopathol. 37:399-426.

Da Rocha, A. and R. Hammerschmidt. 2005. History and perspectives on the use of disease resistance inducers in horticultural crops. HortTechnology 15:518-529. 
Dent, D., 2004. History of pest management. 12 Mar. 2004. <http://www.ipmrc. com/lib/history.shtml>.

Einhellig, F.A. and J.A. Ramussen. 1989. Prior cropping with grain sorghum inhibits weeds. J. Chem. Ecol. 15:951-960.

Herrero, E.V., J.P Mitchell, W.T. Lanini, S.R. Temple, E.M. Miyao, R.D. Morse, E. Campiglia. 2001. Use of cover crop mulches in a no-till furrow-irrigated processing tomato production. HortTechnology 11:43-48.

Janick, J. and I.L. Goldman. 2003. Horticulture, horticultural science, and 100 years of ASHS. HortScience 38(5):883-900.

Kato-Noguchia, H., Y. Tanakaa, T. Murakamib, S. Yamamurac, and S. Fujiharad. 2002. Isolation and identification of an allelopathic substance from peel of Citrus junos. Phytochemistry 61:849-853.

Kremer, R.J. and L. Jianmei. 2003. Developing weed-suppressive soils through improved soil quality management. Soil Tillage Res. 72:193-202.

Liebman, M. and A.S. Davis. 2000. Integration of soil, crop and weed management in low-external-input farming systems. Weed Res. 40:27-47.

Liebl, R.A., F.W. Simmons, L.M. Wax, and E.W. Stoller. 1992. Effect of rye (Secale cereale) mulch on weed control and soil moisture in soybean (Glycine max). Weed Technol. 6:838-846.

Magdoff, F. 2001. Concept, components, and strategies of soil health in agroecosystems. J. Nematol. 33:169-172.

Manning, W.J. and A.V. Tiedemann. 1995. Climate change: Potential effects of increased atmospheric carbon dioxide $\left(\mathrm{CO}_{2}\right)$, ozone $\left(\mathrm{O}_{3}\right)$, and ultraviolet- $\mathrm{B}(\mathrm{UV}$ $\mathrm{B})$ radiation on plant diseases. Environ. Pollution 88:219-245.

McGiffen M., Jr., M. Ngouajio, G. Wang, and S. Yang. 2003. Managing the soil to manage pests. HortScience 28:865.

Ohno, T. and K.L. Doolan. 2001. Effects of red clover decomposition on phytotoxicity to wild mustard seedling growth. Appl. Soil Ecol. 16:187-192.

Ohno, T., K. Doolan, L.M. Zibilske, M. Liebman, E.R. Gallandt, and C. Berube. 2000. Phytotoxic effects of red clover amended soils on wild mustard seedling growth. Agr. Ecosystems Environ. 78:187-192.
Putnam, A.R. 1983. Allelopathic chemicals: Nature's herbicide in action. Chem. Eng. News 61:34-45.

Putnam, A.R. 1988. Allelochemicals from plants as herbicides. Weed Technol. 2:510-518.

Quimby, P.C., L.R. King, and W.E. Grey. 2002. Biological control as a means of enhancing the sustainability of crop/land management systems. Agr. Ecosystems Environ. 88:147-152.

Read, P.E. 2003. Introduction to the proceedings of the workshop History of Horticulture and Human Health. HortTechnology 13(2):226-228.

Rice, E.L. 1995. Biological control of weeds and plant diseases: Advances in applied allelopathy. Univ. of Oklahoma Press, Norman.

Shilling, D.G., R.A. Liebl, and A.D. Worsham. 1985. Rye (Secale cereale L.) and wheat (Triticum aestivum L.) mulch: The suppression of certain broadleaved weeds and the isolation and identification of phytotoxins, p. 243-271. In: A.C. Thompson (ed.). The chemistry of allelopathy: Biochemical interactions among plants. Amer. Chem. Soc., Washington, D.C.

Singh, H.P., D.R. Batish, and R.K. Kohlil . 2003. Allelopathic interactions and allelochemicals: New possibilities for sustainable weed management. Critical Rev. Plant Sci. 22:239-311.

Teasdale, J.R. 1998. Cover crops, smother plants, and weed management, p. 247-270. In: J.L. Hatfield, D.D. Buhler, and B.A. Stewart (eds.). Integrated weed and soil management. Ann Arbor Press, Chelsea, Mich.

Vogel G. and A. Lawler. 1998. Hot year, but cool response in Congress. Science 280:1684.

Weston, L.A. 2005. History and current trends in the use of allelopathy for weed management. HortTechnology 15:529-534.

Weston, L.A. 1996. Utilization of allelopathy for weed management in agroecosystems. Agron. J. 88:860-866.

Weston, L.A. and S.O. Duke. 2003. Weed and crop allelopathy. Critical Rev. Plant Sci. 22:367-389. 